\title{
Forward, backward selection and variation analy- sis of growth traits in half-sib Larix kaempferi fam- ilies
}

\author{
Yanyan Pan ${ }^{1,2}$, Xiaona Pei ${ }^{1}$, Fuwei Wang ${ }^{3}$, Chenglu Wang ${ }^{4}$, Lili Shao ${ }^{4}$, Lihu Dong ${ }^{1}$, Xiyang Zhao ${ }^{*}$, \\ Guan-Zheng Qu'
}

\author{
${ }^{1}$ State Key Laboratory of Tree Genetics and Breeding (Northeast Forestry University), School of Forestry, Northeast \\ Forestry University, Harbin 150040, China; \\ 2 Jilin Provincial Academy of Forestry Sciences, Changchun 130000, China; \\ ${ }^{3}$ Tree Seedling Management Station, Forestry Department of Jilin Province, Changchun 130000, China; \\ ${ }^{4}$ Wudaogou Forestry Center of Liuhe County, Tonghua 135300, China;
}

*Corresponding author: Xiyang Zhao, E-mail: zhaoxyphd@163.com

\begin{abstract}
Tree height and diameter at breast height of 30 half-sib Larix kaempferi families were analyzed at different ages. Analysis of variance revealed a significant difference in growth among different families. Phenotypic variation coefficients of the traits tree height and diameter at breast height among families of different ages ranged from $11.04 \%$ to $31.74 \%$ and $19.01 \%$ to $19.83 \%$, respectively. Average heritability of tree height and diameter at breast height ranged from 0.87 to 0.96 and 0.93 to 0.96 , respectively. Significant positive correlations were observed among all traits at different ages. By the method of multiple-traits comprehensive, six families (L18, L12, L8, L3, L25 and L20) were selected as being elite using a $20 \%$ selection ratio at 12 years of age. Average values of these elite families were $11.15 \%$ and $16.83 \%$ higher than the total average for height and diameter at breast height, and genetic gains were $10.53 \%$ and $15.79 \%$, respectively. Forty five elite individual plants were selected using a $5 \%$ selection ratio which were $23.47 \%$ and $24.90 \%$ higher than the overall average for height and diameter at breast height, respectively.
\end{abstract}

Keywords: : Half-sib; Larix kaempferi; Genetic; Variation; Comprehensive evaluation

\section{Introduction}

Larix kaempferi is one of the most successful exotic species in China, having been introduced from Japan approximately 100 years ago (Toda and Mikami 1976). It is an excellent species for conifer plantations because of its strong adaptability, wide distribution, strong resistance, and rapid growth (Kurinobu 2005). L. kaempferi has been extensively used as materials for building, furniture making, paper manufacture, and biofuel generation (Fukatsu et al. 2013). For centuries, there are many studies on L. kaempferi, including growth traits (Teruyoshi et al. 2014; Hou et al. 2012), wood properties (Cáceres et al. 2017), photosynthetic traits (Watanabe et al. 2011), genetic diversity (Achere 2004), and molecular markers (Moriguchi et al. 2008).

Because cutting and tissue culture was difficult to achieve in L. kaempferi, and grafting showed a severe effect on rootstock, seed orchards are one of the most important improvement methods for $L$. kaempferi. The earliest seed orchards were established in the 1960s (Wang et al. 2000), and many seed orchards were established after that. To date, most of the seed orchards had been flowering and fruiting, and the elite seeds produced were widely used in reforestation (Ding et al. 2002; Zhang, 2013; Zheng et al. 2014). To obtain greater genetic gains, improvement or advanced seed orchards should be established as the next step. Backward selection and forward selection is a necessary channel for improvement of seed orchard construction. Backward selection is a method to choose superior parents, based on the results of progeny testing 
(Cornelius, 1994) with the parents chosen to construct an improved seed orchard. In forward selection, the elite offspring are selected to establish the next generation of seed orchards (Wright, 1976). In L. kaempferi seed orchards, most studies used on genetic variation and genetic gain in growth traits to evaluate offspring (Zhang et al. 2013; Du et al. 2015) with the backward selection and forward selection seldom reported. In this study, tree height $(\mathrm{H})$ and diameter at breast height $(\mathrm{DBH})$ were measured in 30 L. kaempferi families over several growth years, genetic variation parameters were calculated, and elite families in different growth years under different selection ratios were selected. Forward and backward selections were used to construct different improved seed orchards. This research could provide the basis for advaned L. kaempferi breeding.

\section{Materials and Methods}

\section{Experimental sites}

The experimental was conducted in Wudaogou forestry farm (N 41 ${ }^{\circ} 54^{\prime}, \mathrm{E} 125^{\circ} 17^{\prime}$ ), located in Liuhe County, in Jilin Province of northeast China. The area has a continental monsoon climate, the average annual temperature was $5.5^{\circ} \mathrm{C}$, the precipitation was $736 \mathrm{~mm}$, the frost-free season was 145 days, and the duration of sunshine was 2479 hours. L. kaempferi trees grew well at the experimental site with the local climate.

\section{Experimental methods}

A total of 30 L. kaempferi half-sib families (table 4) were used as sources for seed collection in the autumn of 2002. These seeds were sown the following year, and the experimental stand was established in the spring of 2005. The experimental design consisted with 5 blocks and 10 trees row plots was used. The test was established using 2-year old seedling at a spacing of $2 \times 2 m$.

\section{Data measurement}

The tree height $(\mathrm{H} / \mathrm{m})$ of all living and unbroken trees was measured in 2006 (4 years old), 2008 (6 years old), 2010 (8 years old), 2012 (10 years old) and 2014 (12 years old). The diameter at breast height $(\mathrm{DBH} / \mathrm{cm})$ of each tree was measured in 2010 (8 years old), 2012 ( 10 years old) and 2014 (12 years old).

\section{Statistical analyses}

Statistical analysis was carried out using SPSS 19.0 (Statistical Package for the Social Science) software. The significance of fixed effects was tested by analysis of variance (ANOVA) F-tests. Variation among families of the same age was analyzed by ANOVA according to Hansen (1996) as following formula :

$$
\mathrm{y}_{i j}=\mu+\alpha_{i}+\beta_{j}+\alpha \beta_{i j}+\varepsilon_{i j}
$$

where $y_{i j}$ is the performance of an individual of family $i$ within block $j, \mu$ is the overall mean, $a_{i}$ is the radom effect of family $(i=1, \ldots, 30), \beta_{j}$ is the fixed effect of block $(i=1, \ldots, 5), a \beta_{i j}$ is the random effect of family $i$ within block $j$, and $\varepsilon_{i j}$ is the random error.

Phenotypic coefficient of variation PCV (\%) and genotypic coefficient of variance (GCV) were estimated by the formulas below as used by Jonah et al. (2011):

The coefficient of phenotypic variation (PCV) was calculated using the following formula (Zhao et al. 2013b):

$$
\begin{aligned}
& P C V=\frac{\sqrt{\sigma_{p}^{2}}}{\bar{X}} \times 100 \% \\
& G C V=\frac{\sqrt{\sigma_{g}^{2}}}{\bar{X}} \times 100 \%
\end{aligned}
$$

Where $\sigma_{p}{ }^{2}$ is variance components of phenotypic, $\sigma_{g}{ }^{2}$ is variance components of genotypic, $\bar{X}$ is the mean value of a growth character.

Heritability $\left(h^{2}\right)$ was calculated according to Zhao (2013b) as:

$$
h^{2}=\frac{\sigma_{F}{ }^{2}}{{\sigma_{F}}^{2}+\sigma_{F B}{ }^{2} / B+\sigma_{e}{ }^{2} / N B}
$$

Where $h^{2}$ is family heritability, $\sigma_{F}^{2}$ is variance components of family, $\sigma_{F B}{ }^{2}$ is variance components of family by block interaction, $\sigma_{e}^{2}$ is variance components of residual error, $\mathrm{F}$ is the number of families, $B$ is the number of blocks and $N$ is the number of values per family.

The phenotypic correlation coefficient was calculated using the following formula (Fernando et al. 2016):

$$
\mathrm{r}_{A}(x y)=\frac{\sigma_{a(x y)}}{\sqrt{\sigma_{a(x)}^{2} \cdot \sigma_{a(y)}^{2}}}
$$

where $\sigma^{2}{ }_{a(x y)}$ denotes the phenotypic covariance between the traits $x$ and $y$, and $\sigma_{a(x y)}^{2}$ and $\sigma_{a(y)}^{2}$ denote the phenotypic variance of traits $x$ and $y$, respectively.

The phenotypic correlation, $r_{a(x y)}$ of traits $x$ and $y$ was calculated according to Liang et al. (2018 a) as follows:

$$
\mathrm{r}_{\mathrm{A}}(\mathrm{xy})=\frac{\sigma_{\mathrm{a}(\mathrm{xy})}}{\sqrt{\sigma_{a(x)}^{2} \cdot \sigma_{a(y)}^{2}}}
$$

where $\sigma_{a(x)}^{2}$ is the family variance component for trait $x, \sigma_{a(y)}^{2}$ is the family variance component for trait $y$, and $\sigma_{a(x))}^{2}$ is the family covariance component.

The genetic correlation $r_{g}(x y)$ of traits $x$ and $y$ was calculated as Liang et al. (2018 b):

$$
\mathrm{r}_{g}(x y)=\frac{C O V_{g(x y)}}{\sqrt{\sigma_{g_{x}}^{2} \cdot \sigma_{g_{y}}^{2}}}
$$


where $\mathrm{COV}_{\mathrm{g}(\mathrm{xy})}$ is the genetic variation between traits $\mathrm{x}$ and $y$, and $\sigma_{g}^{2}$ and $\sigma_{g}^{2}$ are the variance component for traits in $\mathrm{x}$ and $\mathrm{y}$, respectively.

The estimation of parental breeding values of the traits for all families was calculated according to the phenotypic observed values, and the formula of the breeding value is as follows (Kung FH, 1979):

$$
Z=\bar{Y}+h^{2}(Y-\bar{Y})
$$

where $\mathrm{Z}$ is the breeding value of a trait of each family, $\bar{Y}$ is the overall mean of a trait of all families, $h^{2}$ is the heritability of different traits, and $\mathrm{Y}$ is the average value of a trait of each family.

The comprehensive evaluation was conducted using the method of Qi value evaluation. Qi was calculated as follows (Liu et al. 2015):

$$
Q_{i}=\sqrt{\sum_{j=1}^{n} a_{i}}
$$

where $a_{i}=X_{i j} / X_{\text {jmax' }} Q_{i}$ is the comprehensive valuation value of $i$ family, $X_{i j}$ is the mean of a character, $X_{j \max }$ is the maximum value of a character, and $n$ is the number of evaluation index.

The estimated genetic gain was calculated using the formula (Silva et al. 2008):

$$
\Delta \mathrm{G}=\left(h^{2} \mathrm{~W} / \bar{X}\right) \times 100 \%
$$

where $\Delta \mathrm{G}$ is the genetic gain of a trait for the families, $h^{2}$ is the heritability of the traits, $\mathrm{W}$ is the difference of the average values of the traits between selected families and all families, namely, the selection difference, and $\bar{X}$ is the mean value of a growth character $(\mathrm{H}$ or $\mathrm{DBH})$ among all families.

\section{Results}

\section{Analyses of variance}

ANOVA analysis of $\mathrm{H}$ and $\mathrm{DBH}$ for all families during different ages are shown in Table 1. All variance sources were non-significant except for families. At each age, a significant difference was observed between different families $(P<0.01)$.

\section{Genetic and variation parameters}

Genetic and variation parameters of $\mathrm{H}$ and $\mathrm{DBH}$ among different families are shown in Table 2. The average $\mathrm{H}$ and $\mathrm{DBH}$ of all families varied from 0.42 to $13.20 \mathrm{~m}$ and 3.50 to $19.00 \mathrm{~cm}$, respectively, at different ages. $P C V$ s of $\mathrm{H}$ and $\mathrm{DBH}$ at different ages ranged from $11.04 \%$ to $31.74 \%$ and $19.01 \%$ to $19.83 \%$, respectively. GCVs of $\mathrm{H}$ and $\mathrm{DBH}$ at different ages ranged from $6.83 \%$ to $17.93 \%$ and $11.26 \%$ to $15.12 \%$, respectively. PCVs and GCVs of $\mathrm{H}$ decreased with tree growth. PCVs and GCVs of $\mathrm{DBH}$ were higher than $\mathrm{H}$ from ages 8 to 12 years. The $\underline{\text { Table } 1}$

\begin{tabular}{|c|c|c|c|c|c|c|c|}
\hline Traits & Age & Variance source & SS & df & MS & F & Sig \\
\hline \multirow{24}{*}{$\mathrm{H}$} & \multirow{5}{*}{12} & Block & 0.907 & 4 & 0.227 & 0.291 & 0.886 \\
\hline & & Family & 409.704 & 29 & 14.128 & 18.114 & 0.000 \\
\hline & & Plant & 4.882 & 5 & 0.976 & 1.236 & 0.290 \\
\hline & & Block $\times$ Family & 90.471 & 116 & 0.780 & 0.988 & 0.521 \\
\hline & & Error & 588.323 & 745 & 0.790 & & \\
\hline & \multirow{5}{*}{10} & Block & 0.829 & 4 & 0.207 & 0.218 & 0.919 \\
\hline & & Family & 655.956 & 29 & 22.619 & 23.745 & 0.000 \\
\hline & & Plant & 5.679 & 5 & 1.136 & 1.287 & 0.267 \\
\hline & & Block $\times$ Family & 110.498 & 116 & 0.953 & 1.079 & 0.281 \\
\hline & & Error & 657.478 & 745 & 0.883 & & \\
\hline & \multirow{5}{*}{8} & Block & 0.577 & 4 & 0.144 & 0.419 & 0.866 \\
\hline & & Family & 198.877 & 29 & 6.858 & 19.937 & 0.000 \\
\hline & & Plant & 1.765 & 5 & 0.353 & 0.779 & 0.565 \\
\hline & & Block $\times$ Family & 39.901 & 116 & 0.344 & 0.759 & 0.968 \\
\hline & & Error & 337.632 & 745 & 0.453 & & \\
\hline & \multirow{5}{*}{6} & Block & 0.220 & 4 & 0.055 & 0.551 & 0.751 \\
\hline & & Family & 39.098 & 29 & 1.348 & 13.514 & 0.000 \\
\hline & & Plant & 0.426 & 5 & 0.085 & 0.742 & 0.592 \\
\hline & & Block $\times$ Family & 11.572 & 116 & 0.100 & 0.869 & 0.826 \\
\hline & & Error & 85.479 & 745 & 0.115 & & \\
\hline & \multirow{5}{*}{4} & Block & 0.070 & 4 & 0.017 & 0.449 & 0.816 \\
\hline & & Family & 8.732 & 29 & 0.301 & 7.722 & 0.000 \\
\hline & & Plant & 0.261 & 5 & 0.052 & 1.161 & 0.327 \\
\hline & & Block $\times$ Family & 4.524 & 116 & 0.039 & 0.869 & 0.828 \\
\hline \multirow{16}{*}{ DBH } & & Error & 33.442 & 745 & 0.045 & & \\
\hline & \multirow{5}{*}{12} & Block & 14.029 & 4 & 3.507 & 0.983 & 0.432 \\
\hline & & Family & 1679.773 & 29 & 57.923 & 16.236 & 0.000 \\
\hline & & Plant & 6.676 & 5 & 1.352 & 0.368 & 0.871 \\
\hline & & Block $\times$ Family & 413.838 & 116 & 3.568 & 0.970 & 0.571 \\
\hline & & Error & 2739.240 & 745 & 3.677 & & \\
\hline & \multirow{5}{*}{10} & Block & 2.113 & 4 & 0.528 & 0.398 & 0.845 \\
\hline & & Family & 916.913 & 29 & 31.618 & 23.838 & 0.000 \\
\hline & & Plant & 4.656 & 5 & 0.931 & 0.615 & 0.689 \\
\hline & & Block $\times$ Family & 153.861 & 116 & 1.326 & 0.875 & 0.814 \\
\hline & & Error & 1128.736 & 745 & 1.515 & & \\
\hline & \multirow{5}{*}{8} & Block & 1.467 & 4 & 0.367 & 0.480 & 0.792 \\
\hline & & Family & 320.677 & 29 & 11.058 & 14.466 & 0.000 \\
\hline & & Plant & 6.523 & 5 & 1.305 & 1.506 & 0.186 \\
\hline & & Block $\times$ Family & 88.669 & 116 & 0.764 & 0.882 & 0.800 \\
\hline & & Error & 645.610 & 745 & 0.867 & & \\
\hline
\end{tabular}

ANOVA analysis of $\mathrm{H}$ and DBH of L. kaempferi families in different growth years

heritability of $\mathrm{H}$ increased with tree growth; all values were greater than 0.87 , with a maximum of 0.96 . All values of $\mathrm{DBH}$ were greater than 0.93 , representing a high heritability. The variance components of $\mathrm{H}$ and $\mathrm{DBH}$ increased with tree growth and development with values of 0.0087 to 0.7222 and 0.3431 to 1.8119 , respectively.

Table 2

Genetic and variation parameters of different families in different growth years

\begin{tabular}{cccccccc}
\hline Traits & Age & $\begin{array}{c}\text { Variation } \\
\text { range }\end{array}$ & $\bar{X} \pm \mathrm{SD}$ & $P C V$ & $G C V$ & $h^{2}$ & $\sigma$ \\
\hline & 4 & $0.42-1.46$ & $0.81 \pm 0.26$ & 31.74 & 17.93 & 0.87 & 0.0087 \\
& 6 & $1.85-3.95$ & $2.46 \pm 0.42$ & 17.06 & 10.05 & 0.93 & 0.0416 \\
$\mathrm{H}$ & 8 & $3.00-7.80$ & $5.44 \pm 0.87$ & 15.93 & 10.03 & 0.95 & 0.2171 \\
& 10 & $5.00-10.80$ & $8.46 \pm 1.28$ & 15.10 & 10.23 & 0.96 & 0.7222 \\
& 12 & $7.00-13.20$ & $10.25 \pm 1.13$ & 11.04 & 6.83 & 0.94 & 0.4449 \\
& 8 & $3.50-8.50$ & $6.08 \pm 1.16$ & 19.01 & 11.26 & 0.93 & 0.3431 \\
DBH & 10 & $4.50-13.00$ & $8.36 \pm 1.66$ & 19.83 & 15.12 & 0.96 & 1.0097 \\
& 12 & $6.00-19.00$ & $12.07 \pm 2.37$ & 19.62 & 11.51 & 0.94 & 1.8119 \\
\hline
\end{tabular}

Note: the unit of $\mathrm{H}$ was $\mathrm{m}, \mathrm{DBH}$ was $\mathrm{cm}$, the unit of $\mathrm{PCV}$ and $\mathrm{GCV}$ was $\%$. 


\section{Correlation analysis}

The results of phenotypic and genetic correlation analyses are shown in Table 3. All phenotypic correlation coefficients between growth traits were significantly and positively correlated. Correlation coefficients of $\mathrm{H}$ at different ages varied from 0.459 ( 4 and 10 years of age) to 0.785 ( 4 and 6 years of age). Correlation coefficients of DBH at different ages varied from 0.647 (8 and 10 years of age) to 0.853 ( 10 and 12 years of age). Correlation coefficients between growth traits at different ages ranged from 0.514 (between the $\mathrm{H}$ of the 10-year-old trees and the DBH of the 8-year-old trees) to 0.933 (between the $\mathrm{H}$ and the DBH of the 8-year-old trees). Genetic correlation is stable for inheritance and more important for breeding, but it is difficult to reach the level of statistical significance because of the large sampling error in the estimation of genetic correlation. Therefore, significance test was not conducted. The genetic correlation coefficients were closely to phenotypic correlation coefficients, which ranged from 0.252 (between 6-year-old $\mathrm{H}$ and 10-year-old) to 0.935 (between the $\mathrm{H}$ and the $\mathrm{DBH}$ of the 8-year-old).

Table 3

Correlation analysis of different traits in different growth years

\begin{tabular}{cccccccccc}
\hline \multirow{2}{*}{ Traits } & \multicolumn{9}{c}{$\mathrm{H}$} \\
\cline { 2 - 10 } & & 4 & 6 & 8 & 10 & 12 & 8 & 10 & 12 \\
\hline \multirow{4}{*}{$\mathrm{H}$} & 1 & 0.423 & 0.854 & 0.518 & 0.759 & 0.912 & 0.712 & 0.701 \\
& $6 \mathrm{H}$ & $0.785^{* *}$ & 1 & 0.470 & 0.252 & 0.389 & 0.411 & 0.275 & 0.403 \\
& $8 \mathrm{H}$ & $0.754^{* *}$ & $0.756^{* *}$ & 1 & 0.627 & 0.673 & 0.935 & 0.756 & 0.716 \\
& $10 \mathrm{H}$ & $0.459^{*}$ & $0.677^{* *}$ & $0.630^{* *}$ & 1 & 0.743 & 0.513 & 0.785 & 0.774 \\
& $12 \mathrm{H}$ & $0.668^{* *}$ & $0.744^{* *}$ & $0.678^{* *}$ & $0.742^{* *}$ & 1 & 0.659 & 0.811 & 0.930 \\
& $8 \mathrm{DBH}$ & $0.771^{* *}$ & $0.692^{* *}$ & $0.933^{* *}$ & $0.514^{* *}$ & $0.659^{* *}$ & 1 & 0.669 & 0.661 \\
DBH & $10 \mathrm{DBH}$ & $0.602^{* *}$ & $0.765^{* *}$ & $0.729^{* *}$ & $0.814^{* *}$ & $0.824^{* *}$ & $0.647^{* *}$ & 1 & 0.845 \\
& $12 \mathrm{DBH}$ & $0.624^{* *}$ & $0.771^{* *}$ & $0.716^{* *}$ & $0.775^{* *}$ & $0.931^{* *}$ & $0.659^{* *}$ & $0.853^{* *}$ & 1 \\
\hline Note: **correlation is significant at the 0.01 level $(2$-tailed).Left and lower triangle represent
\end{tabular}
phenotypic correlation, right and upper represent genetic correlation.

Breeding value of Height in different growth year Breeding values of $\mathrm{H}$ among all families were ranked. The top ranked family was scored at 30 points, the second at 29 points, and so on, with the last family scored at 1 point. Finally, $\mathrm{H}$ was also ranked according to the same 1 to 30 scoring method. The analysis for the breeding values of $\mathrm{H}$ for different families, and the ranking results, are shown in table 4 . Values varied for different ages of trees. The overall average breeding values of $\mathrm{H}$ for all families ranged from $0.82 \mathrm{~m}$ to $10.32 \mathrm{~m}$ at different ages. In years $4,6,8,10$ and 12, families L18, L20, L18, L18 and L18 showed higher total scores than other families, respectively. Families L4, L23, L4, L23 and L23 showed lower total scores than other families at different ages.
Table 4

Breeding values of $\mathrm{H}$ among different families in different growth years

\begin{tabular}{|c|c|c|c|c|c|c|c|c|c|c|c|c|c|c|c|}
\hline \multirow[b]{2}{*}{ Families } & \multicolumn{3}{|c|}{ The \& $4^{\text {grouth tyar }}$} & \multicolumn{3}{|c|}{ The $\mathrm{f}^{\text {g govoth }}$ year } & \multicolumn{3}{|c|}{ The $e^{\text {t grovith year }}$} & \multicolumn{3}{|c|}{ 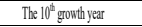 } & \multicolumn{3}{|c|}{ The $12^{\text {h grovith year }}$} \\
\hline & $\begin{array}{l}\text { breating } \\
\text { value }\end{array}$ & Rank & Scorers & $\begin{array}{c}\text { breading } \\
\text { value }\end{array}$ & Rank & Scores & $\begin{array}{l}\text { breding } \\
\text { value }\end{array}$ & Rank & Scoves & $\begin{array}{l}\text { breeding } \\
\text { value }\end{array}$ & Rank & Scores & $\begin{array}{l}\text { breeding } \\
\text { value }\end{array}$ & Rank & Sores \\
\hline $\mathrm{Ll}$ & 0.84 & 17 & 14 & 2.39 & 23 & 8 & 5.66 & 12 & 19 & 7.46 & 27 & 4 & 9.80 & 25 & 6 \\
\hline L2 & 0.86 & 10 & 21 & 2.50 & 13 & 18 & 5.86 & 5 & 26 & 9.21 & 6 & 25 & 10.49 & 10 & 21 \\
\hline L3 & 0.87 & 8 & 23 & 2.61 & 4 & 27 & 5.79 & 8 & 23 & 9.17 & 8 & 23 & 11.32 & 3 & 28 \\
\hline LA & 0.69 & 30 & 1 & 2.30 & 29 & 2 & 4.69 & 30 & 1 & 7.37 & 29 & 2 & 9.66 & 29 & 2 \\
\hline L6 & 0.78 & 23 & 8 & 2.41 & 20 & 11 & 5.56 & 14 & 17 & 8.58 & 16 & 15 & 9.95 & 20 & II \\
\hline L7 & 0.80 & 21 & 10 & 2.32 & 26 & 5 & 5.17 & 24 & 7 & 7.44 & 28 & 3 & 9.98 & 19 & 12 \\
\hline Ls & 0.85 & 13 & 18 & 2.51 & 11 & 20 & 5.86 & 6 & 25 & 9.12 & 9 & 22 & 11.32 & 4 & 27 \\
\hline L9 & 0.84 & 16 & 15 & 2.47 & 17 & 14 & 5.24 & 21 & 10 & 7.50 & 26 & 5 & 9.86 & 22 & 9 \\
\hline L10 & 0.87 & 6 & 25 & 2.56 & 8 & 23 & 5.87 & 4 & 27 & 9.01 & 12 & 19 & 10.49 & 9 & 22 \\
\hline LII & 0.75 & 26 & 5 & 2.37 & 25 & 6 & 5.42 & 16 & 15 & 7.69 & 23 & 8 & 9.68 & 28 & 3 \\
\hline LI2 & 0.87 & 4 & 27 & 2.65 & 3 & 28 & 5.90 & 2 & 29 & 9.24 & 3 & 28 & 11.66 & 2 & 29 \\
\hline LI3 & 0.81 & 20 & "I & 2.41 & 19 & 12 & 5.23 & 22 & 9 & 7.79 & 22 & 9 & 9.78 & 26 & 5 \\
\hline L.14 & 0.86 & 11 & 20 & 2.56 & 7 & 24 & 5.69 & 11 & 20 & 9.06 & 11 & 20 & 10.42 & 12 & 19 \\
\hline Ll5 & 0.86 & 12 & 19 & 2.55 & 10 & 21 & 5.26 & 19 & 12 & 9.06 & 10 & 21 & 10.53 & 8 & 23 \\
\hline Ll6 & 0.77 & 25 & 6 & 2.43 & 18 & 13 & 5.32 & 18 & 13 & 7.93 & 19 & 12 & 9.72 & 27 & 4 \\
\hline L17 & 0.87 & 7 & 24 & 2.56 & 9 & 22 & 5.50 & 15 & 16 & 8.4 & 17 & 14 & 10.37 & 13 & 18 \\
\hline LI8 & 0.89 & 1 & 30 & 2.73 & 2 & 29 & 5.96 & 1 & 30 & 9.25 & 1 & 30 & 11.79 & 1 & 30 \\
\hline L19 & 0.78 & 22 & 9 & 2.31 & 27 & 4 & 4.92 & 29 & 2 & 7.89 & 20 & II & 10.28 & 15 & 16 \\
\hline L20 & 0.88 & 2 & 29 & 2.76 & 1 & 30 & 5.12 & 26 & 5 & 9.24 & 2 & 29 & 10.89 & 5 & 26 \\
\hline L21 & 0.83 & 18 & 13 & 2.50 & 14 & 17 & 5.16 & 25 & 6 & 8.62 & 15 & 16 & 10.34 & 14 & 17 \\
\hline $\mathrm{L} 22$ & 0.87 & 5 & 26 & 2.51 & 12 & 19 & 5.76 & 10 & 21 & 9.22 & 5 & 26 & 10.46 & 11 & 20 \\
\hline L23 & 0.72 & 29 & 2 & 2.27 & 30 & 1 & 5.79 & 7 & 24 & 7.27 & 30 & 1 & 9.56 & 30 & 1 \\
\hline L24 & 0.87 & 9 & 22 & 2.61 & 5 & 26 & 5.79 & 9 & 22 & 9.21 & 7 & 24 & 10.65 & 7 & 24 \\
\hline $\mathrm{L}_{25}$ & 0.88 & 3 & 28 & 2.61 & 6 & 25 & 5.89 & 3 & 28 & 9.22 & 4 & 27 & 10.85 & 6 & 25 \\
\hline L26 & 0.85 & 14 & 17 & 2.50 & 15 & 16 & 5.18 & 23 & 8 & 7.60 & 24 & 7 & 9.87 & 21 & 10 \\
\hline L27 & 0.81 & 19 & 12 & 2.31 & 28 & 3 & 5.06 & 28 & 3 & 7.82 & 21 & 10 & 10.10 & 17 & 14 \\
\hline L28 & 0.74 & 27 & 4 & 2.39 & 22 & 9 & 5.07 & 27 & 4 & 8.70 & 14 & 17 & 10.16 & 16 & 15 \\
\hline L29 & 0.77 & 24 & 7 & 2.40 & 21 & 10 & 5.35 & 17 & 14 & 8.30 & 18 & 13 & 9.82 & 24 & 7 \\
\hline L30 & 0.84 & 15 & 16 & 2.49 & 16 & 15 & 5.59 & 13 & 18 & 7.50 & 25 & 6 & 9.86 & 23 & 8 \\
\hline L31 & 0.74 & 28 & 3 & 2.37 & 24 & $?$ & 5.25 & 20 & 11 & 8.96 & 13 & 18 & 10.02 & 18 & 13 \\
\hline Averageve values & 0.82 & - & - & 2.48 & - & - & 5.46 & - & - & 8.43 & - & - & 10.32 & - & - \\
\hline
\end{tabular}

\section{Comprehensive evaluation}

The results of Multi-traits comprehensive evaluation were shown in Table 5. Elite families were selected by $\mathrm{H}$ values (at ages 4 and 6 years) and Qi values (at ages 8, 10, and 12 years) with different selection ratios at different years. Different numbers of families (18 families at ages 4; 15 at age $6 ; 12$ at age 8,9 at age 10 ; , and 6 at age 12) were selected as elite families (Table 5) using different selection ratios. Additionally, the rank of different families varied according to age, although families L18, L12, L8, L3, L25, and L20 were always selected as elite families at different ages under different selection ratios. Family L18 showed the highest values of $\mathrm{H}$ or $\mathrm{Qi}$ at different ages. Family L24 grew fast during the early stages, but its low Qi value indicated that its DBH was poor, so it was not selected as an elite family at age 12 . Conversely, family L8 grew slowly in the early stages but showed a higher Qi value later on.

Using a comprehensive evaluation method, six families (L18, L12, L8, L3, L25 and L20) were selected as elite families using a $20 \%$ selection ratio at 12 years of age. The average $\mathrm{H}$ and $\mathrm{DBH}$ of the elite families were higher than the total average by $11.15 \%$ and $16.83 \%$, -the genetic gains of $\mathrm{H}$ and $\mathrm{DBH}$ were $10.53 \%$ and $15.79 \%$, respectively. Under the $5 \%$ selection ratio, 45 elite individual plants were selected at age 12 (Table 6). Average $\mathrm{H}$ and $\mathrm{DBH}$ of elite individual plants were $12.65 \mathrm{~m}$ and $15.07 \mathrm{~cm}$, which were $23.47 \%$ and $24.90 \%$ higher than the overall average, respectively. 
$\underline{\text { Table } 5}$

Elite families selected under different selected ratio in different growth years

\begin{tabular}{|c|c|c|c|c|c|c|c|c|c|}
\hline \multicolumn{2}{|c|}{ The $4^{\text {th }}$ growth year } & \multicolumn{2}{|c|}{ The $6^{\text {th }}$ growth year } & \multicolumn{2}{|c|}{ The $8^{\text {th }}$ growth year } & \multicolumn{2}{|c|}{ The $10^{\text {th }}$ growth year } & \multicolumn{2}{|c|}{ The $12^{\text {th }}$ growth yea } \\
\hline Family & $\mathrm{H}$ & Family & $\mathrm{H}$ & Family & Qi & Family & Qi & Family & Qi \\
\hline L18 & 0.96 & L18 & 1.68 & L18 & 1.27 & L18 & 1.29 & L18 & 1.31 \\
\hline L24 & 0.95 & L24 & 1.67 & L8 & 1.25 & L8 & 1.27 & L12 & 1.28 \\
\hline L25 & 0.95 & L12 & 1.64 & L25 & 1.25 & L10 & 1.26 & L8 & 1.27 \\
\hline L12 & 0.95 & L3 & 1.63 & L20 & 1.25 & L20 & 1.26 & L3 & 1.26 \\
\hline L22 & 0.95 & L20 & 1.63 & L2 & 1.24 & L25 & 1.26 & L25 & 1.24 \\
\hline L10 & 0.94 & L25 & 1.63 & L12 & 1.24 & L12 & 1.26 & L20 & 1.24 \\
\hline L17 & 0.94 & L14 & 1.61 & L3 3 & 1.24 & L24 & 1.26 & & \\
\hline L3 & 0.94 & L10 & 1.61 & L22 & 1.24 & L3 & 1.25 & & \\
\hline L20 & 0.94 & L17 & 1.61 & L24 & 1.23 & L2 & 1.25 & & \\
\hline L2 & 0.94 & L15 & 1.60 & L10 & 1.22 & & & & \\
\hline L14 & 0.94 & L8 & 1.59 & L14 & 1.22 & & & & \\
\hline L15 & 0.94 & L22 & 1.59 & L6 & 1.21 & & & & \\
\hline L8 & 0.93 & L2 & 1.59 & & & & & & \\
\hline L26 & 0.93 & L21 & 1.58 & & & & & & \\
\hline L30 & 0.92 & L26 & 1.58 & & & & & & \\
\hline L9 & 0.92 & & & & & & & & \\
\hline L1 & 0.92 & & & & & & & & \\
\hline L21 & 0.92 & & & & & & & & \\
\hline
\end{tabular}

Table 6

Elite individual plant selected under a $5 \%$ selected ratio in the12th growth year

\begin{tabular}{ccccccccc}
\hline single plant & family & $\mathrm{H}$ & single plant & family & $\mathrm{H}$ & single plant & family & $\mathrm{H}$ \\
\hline 661 & 25 & 13.20 & 456 & 18 & 12.80 & 450 & 18 & 12.50 \\
662 & 25 & 13.20 & 79 & 2 & 12.70 & 657 & 25 & 12.50 \\
97 & 3 & 13.00 & 437 & 18 & 12.70 & 434 & 18 & 12.40 \\
179 & 8 & 13.00 & 451 & 18 & 12.70 & 449 & 18 & 12.40 \\
187 & 8 & 13.00 & 458 & 18 & 12.70 & 514 & 20 & 12.40 \\
306 & 12 & 13.00 & 459 & 18 & 12.70 & 515 & 20 & 12.40 \\
433 & 18 & 13.00 & 303 & 12 & 12.60 & 516 & 20 & 12.40 \\
454 & 18 & 13.00 & 304 & 12 & 12.60 & 439 & 18 & 12.30 \\
457 & 18 & 13.00 & 308 & 12 & 12.60 & 506 & 20 & 12.30 \\
460 & 18 & 13.00 & 318 & 12 & 12.60 & 524 & 20 & 12.30 \\
513 & 20 & 13.00 & 249 & 10 & 12.50 & 525 & 20 & 12.30 \\
527 & 20 & 13.00 & 250 & 10 & 12.50 & 526 & 20 & 12.30 \\
452 & 18 & 12.90 & 316 & 12 & 12.50 & 564 & 22 & 12.30 \\
448 & 18 & 12.80 & 317 & 12 & 12.50 & 619 & 24 & 12.30 \\
455 & 18 & 12.80 & 361 & 14 & 12.50 & 557 & 22 & 12.10 \\
\hline & & & & & & & &
\end{tabular}

\section{Discussion}

\section{ANOVA}

ANOVA analysis is one of the most important methods for estimating the extent of variability, and plays an essential role in selecting breeding populations (Zhao et al. 2014). In this research, a significant difference was observed among different families at different ages $(P<0.01)$. This finding indicated the existence of plentiful variation in growth traits among different families. These results are similar to the previous studies (e.g., Nakada et al. 2005), showing that selection of elite families is effective.

\section{Variation and genetic}

It is critical to the efficient usage of genetic resources by understanding the relationship of genetic variation within individuals or populations in breeding research (Hortensia et al. 2011). Large genetic variation and high heritability are requirements to achieve selection progress (Kroon et al. 2011; Kaushik et al. 2015). In this research, we observed high levels of heritability, the values of $\mathrm{H}$ ranging from 0.87 to 0.96 and $\mathrm{DBH}$ values all
$>0.93$, indicating that tree growth is weakly influenced by environmental effects. The PCVs of $\mathrm{H}$ decreased with tree growth, especially at age 12 , when the value was $11.04 \%$, indicating that phenotypic variation among families was small. The PCVs of $\mathrm{H}$ were lower than those for DBH from ages 8 to 12 , suggesting that $\mathrm{DBH}$ is more effective than $\mathrm{H}$ in selecting elite families. This result is in agreement with the previous studies by Zas et al. 2004 and Collet and Chenost 2006.

Different variation trends with age were found for growth traits. We took measurements at various ages, and we observed that $h^{2}$ for $\mathrm{H}$ and $\mathrm{DBH}$ increased with tree growth, which was similar to the pattern seen in Pinus taeda (Gwaze et al. 2001) and Norway spruce (Isik et al. 2010). The $h^{2}$ of $\mathrm{H}$ and DBH increased with tree growth, which represented a higher heritability and were controlled genetically at a higher level, indicating that a fairly large genetic gain could be obtained through the selection of elite families. Variance components and heritability reflected the degree of genetic control of trait variation (Sun 2003). The age trends of variance components for growth traits may present different rules in different environment conditions (Diao et al. 2016). The variance components for H showed an increasing trend, but DBH first increased and then decreased with age at the Hubei experiment site (Diao et al. 2016). However, the variance components for $\mathrm{H}$ and $\mathrm{DBH}$ increased with time on the whole at the Liaoning experiment site in China (Diao et al. 2016). In this research, the variance components for $\mathrm{H}$ and $\mathrm{DBH}$ generally increased as the trees grew. This finding is in agreement with the results for Scots pine (Haapanen 2001) and Douglas fir (Dean and Stonecypher 2006), which displayed variation of $\mathrm{H}$ or $\mathrm{DBH}$ mainly controlled by additive genetic variance in this research.

\section{Correlation analysis}

In breeding programs, correlation coefficients could reflect the relationships between different traits and, therefore, have major implications for breeding strategies (Goncalves et al. 2005; Lee et al. 2002). The relationship of parameters between growth traits is rather complex (Sumida et al. 2013). In previous work, age-age correlations of growth traits reached a very high level at early stages in Pinus taeda (Xiang et al. 2013) and Masson pine (Zeng et al. 2013). In our research, there existed a significant positive correlation between all growth traits, indicating the possibility of early elite family evaluation and selection, which agrees with previous findings in L. olgensis (Xia et al. 2016), Radiata pine (Kumar and Lee 2002), and Populus deltoides (Dhillon et al. 2010).

At present, early selection could shorten breeding process as much as possible, which is an important method. The optimal age of early selection can be predicted by correlation coefficient, heritability and age trends of genetic parameters for growth traits (Svensson et al. 1999). Because of the different selected breeding objectives, there were different optimum early selection ages for L. kaempferi (Fujimoto et al. 2006). For growth traits, tree height was most ideal index for early selection in tree breeding (Balocchi et al. 1993), and the optimum early selection ages were 2, 4, 8 and 10 years for $\mathrm{H}$ in L. kaempferi. In this research, $\mathrm{H}$ was selected as an early evaluation 
index, with the same selection ratio (20\%), and the same elite families were selected at ages 6 and 12 years. Results indicated that the 6 year selection age was the optimum for early selection, which can shorten the breeding cycle for next generation breeding programs.

\section{Comprehensive evaluation}

Comprehensive evaluation and selection for the same characteristics in different growth years are important for tree genetics and breeding to obtain stable characteristics (Kang 1985). However, in previous studies, the selecting of too many characteristics together could lead to low genetic gains in individual characteristics (Guan et al. 2005), resulting in an imprecise selection target. $\mathrm{H}$ and $\mathrm{DBH}$ are vital characteristics for the evaluation of tree growth that could make comprehensive evaluation more effective and reliable (Gwaze and Bridgwater 2002). In this study, different families had different growth patterns (Jansson et al. 2003), especially families L18 and L24 that showed opposing $\mathrm{H}$ and $\mathrm{DBH}$ values. Though the family ranks varied according to year, families L18, L12, L8, L3, L25 and L20 were always selected as elite families under different selection ratios, indicating that appropriate selection ratio and age are vital for elite family selection (Leksono et al. 2006).

Genetic gain is a crucial parameter for selecting elite families (Huang et al. 2006) and is often used as a measure for selection (Hannrup et al. 2000). Most breeding programs purposes are to achieve higher genetic gain, which can be realized by selection (Montes et al. 2008), and relatively high genetic gains have been observed when selection is dependent on high heritability, extensive of genetic variation, and low selection rate (Zhou et al. 2014). In this research, the genetic gains of $H$ and $\mathrm{DBH}$ were higher than that achieved in previous studies on Hybrid L. gmelinii (Cao 2016) and L. gmelinii (Liu and Wang 2016), which were $10.53 \%$ and $15.79 \%$, respectively, although these data could reflect differences in species (Yin et al. 2016). Using a $5 \%$ selection ratio in 12 year old trees, 45 elite individual plants were selected, average $\mathrm{Hs}$ and DBHs of selected elite individual plants were $12.65 \mathrm{~m}$ and $15.07 \mathrm{~cm}$, which were 23.47 $\%$ and $24.90 \%$ higher than overall average, respectively.

\section{Backward selection and forward selection}

Backward and forward selections are affected by heritability, intensity of selection and genetic gain, but the relationships between these parameters vary (Hodge and White, 1993). Low heritability is favour to backward selection, which is one of the main factors supporting progeny testing, because on this occasion forward selection is not effective (Falconer and Mackey, 1996). In this research, heritabilities of $\mathrm{H}$ and DBH were higher than 0.87 , which indicates higher heritability, therefore the forward selection is more effective.

Genetic gain is the most direct index to reflect improvement of seed orchards (Bai et al. 2012). In this research, 6 elite families were selected using a $20 \%$ selection rate, and the genetic gains of $\mathrm{H}$ and $\mathrm{DBH}$ were $10.53 \%$ and $15.79 \%$, respectively. These results were greater than those found in previous research (Zhang et al. 2013), where genetic gains of $\mathrm{H}$ and DBH for the family of Japanese larch were $7.5 \%$ and $10.3 \%$, respectively, on progeny test forests with open pollination. High genetic gain elite families were more suitable for the establishment of improved seed orchards.

\section{Breeding Values}

Breeding values can be predicted for each family and offspring (Namkoong et al. 1966). In this research, the breeding value scores of different families also varied with different ages, but the elite families exhibited higher scores in the same stage, which were similar with the selected families using the method of a Qi value under the $20 \%$ selection ratio in the 12 year old tree. e.g., family F18. Therefore, breeding value scores were more accurate and stable for selection while conducting Qi value with the breeding value concerned (Israel C et al., 2000; Pan $X Q$, 2014). Selected families could be utilized as excellent subjects for the establishment of improved seed orchards, and it could also provide the theoretical basis for excellent family selection and evaluation of L. kaempferi.

\section{Conclusion}

The early evaluation and selection of elite families is important for shortening the breeding cycle and improving breeding efficiencies of tree species. In this research, the genetic and variation parameters among different families were observed to vary based on age. 6 elite families and 45 12-year-old elite individual plants were selected using a $20 \%$ and the $5 \%$ selection ratio. Selected elite families and plants can provide characteristics for the establishment of improved or next generation seed orchards. These could be used for future afforestation, and the research can directly apply to other conifer breeding programs. Additionally, the technique could provide the theoretical basis for early selection of other tree species. Further research on L. kaempferi should focus on wood properties, flowering rules, stress resistance, and molecular breeding.

\section{Acknowledgements}

This work was supported by "the National key R \& D plan project" (No. 2017YFD0600402) and the Innovation Project of State Key Laboratory of Tree Genetics and Breeding (Northeast Forestry University) (No. 2016C02).

\section{References}

Achere V (2004) Chloroplast and mitochondrial molecular tests identify European× Japanese larch hybrids. Theor Appl Genet 108: 1643-1649 https://doi.org/10.1007/s00122-004-1595-y

Bai TD, Xu LA, Wang ZR, Lin NQ, Zhang SH (2012) Estimation of parents genetic gain by open-pollinated progeny test of seedling seed orchard of Masson pine. Forest Research 25(4): 449-455 
Balocchi C, Bridgwater F, Zobel B, Jahromi S (1993) Age trends in genetic parameters for tree height in a nonselected population of loblolly pine. Forest Sci 39(2): 231-251

Cao Y (2016) Preliminary selection of superior families of Hybrid Larix gmelinii. Protection Forest Science and Technology 12: 26-36

Collet C, Chenost C (2006) Using competition and light estimates to predict diameter and height growth of naturally regenerated beech seedlings growing under changing canopy conditions. Forestry 79(5): 489-502 https://doi.org/10.1093/forestry/cpl033

Cornelius J (1994) Heritabilities and additive genetic coefficients of variation in forest trees. Canadian Journal of Forest Research 24: 372-379 https://doi.org/10.1139/x94-050

Dean CA, Stonecypher RW (2006) Early selection of Douglas-fir across south central coastal Oregon, USA. Silvae Genetica 55(3): 135-140 https://doi.org/10.1515/sg-2006-0019

Dhillon G, Singh A, Singh P, Sidhu DS (2010) Field evaluation of Populus deltoides Bartr. ex Marsh. at two sites in Indo-gangetic plains of India. Silvae Genetica 59: 1-7.https://doi.org/10.1515/sg-2010-0001

Diao S, Hou YM, Xie YH, Sun XM (2016) Age trends of genetic parameters, early selection and family by site interactions for growth traits in Larix kaempferi open-pollinated families. BMC Genetics 17: 104-115 https://doi.org/10.1186/s12863-016-0400-7

Ding ZF, Wang JZ, Fang HF, Zhang XT, Yin YQ (2002) The growth of half-sib prog eny in Larix kaempferi primary seed orchard. Journal of Forestry University 30(2): 9-12

Falconer DS, Mackey TFC (1996) Introduction to quantitative genetics. 4th ed. Longman Group, London, UK. 463

Fernando PG, James HR, Oliver F, Randi F, Brian JS, Richard S, Robert S, Mark FD, David BN (2016) Analysis of the genetic variation in growth, ecophysiology, and chemical and metabolomic composition of wood of Populus trichocarpa provenances. Tree Genetics \& Genomes 15: 965-972 https://doi.org/10.1007/s11295-015-0965-8

Fujimoto T, Kita K, Uchiyama K (2006) Age trends in the genetic parameters of wood density and the relationship with growth rates in hybrid larch (Larix gmelinii var. japonica $\times$ L. kaemferi) F1. The Japanese Forest Society and Springer Verlag Tokyo 11: 157-163 https://doi.org/10.1007/s10310-005-0200-9

Fukatsu E, Tsubomura M, Fujisawa Y, Nakada R (2013) Genetic improvement of wood density and radial growth in Larix kaempferi: results from a dialle mating test. Annals of Forest Science 70: 451-459 https://doi.org/10.1007/s13595-013-0278-8

Gapare WJ, Ivkovi'c M, Powell MB, McRae TA, Wu HX (2008) Genetics of shrinkage in juvenile trees of Pinus radiata D. Don from two test sites in Australia. Silvae Genet 57:145-151. https://doi.org/10.1515/sg-2008-0022

Goncalves P, Bortoletto N, Cardinal A, Gouvea L, Costa R, MoraesM (2005) Ageage correlation for early selection of rubber tree genotypes in Sao Paulo State, Brazil. Genet Mol Biol 28: 758-764 https://doi.org/10.1590/s1415-47572005000500018

Guan LH, Pan HX, Huang, Shi JS (2005) Research on growth and wood properties joint genetic improvement of new clones of Poplus deltoids (I-69) $\times P$. euramericana (I-45). Journal of Nanjing Forestry University 29(2):6-10

Gwaze DP, Bridgwater FE (2002) Determining optimum selection age for diameter and height in loblolly pine (Pinus taeda). For Genet 9:159-165

Gwaze DP, Wolliams JA, Kanowski PJ, Bridgwater FE (2001) Interactions of genotype with site for height and stem straightness in Pinus taeda in Zimbabwe. Silvae Genet 50:135-140

Haapanen M (2001) Time trends in genetic parameter estimates and selection efficiency for Scots pine in relation to field testing method. Forest Genetics 8: 129-144

Hannrup B, Elberg I, Persson A (2000) Genetic correlations among wood, growth capacity and stem traits in Pinus sylvetris. Scand. J. For. Res 15: 161-170 https://doi.org/10.1080/028275800750014966

Hansen J, Roulund H (1996) Genetic parameters for spiral grain, stem form, pilodyn and growth in 13 years old clones of Sitka Spruce (Picea sitchensis (Bong.) Carr.). Silvae Genet 46: 107-113

Hodge GR and White TL (1993) Advanced generation wind-pollinated seed orchard design. New Forests 7: 213-236. https://doi.org/10.1007/bf00127387
Hortensia S, Jordi S, Marcos B, Ciria MP, Isabel C (2011) Genetic variation and genotype-environment interactions in short rotation Populus plantations in southern Europe. New Forests 42: 163-177 https://doi.org/10.1007/s11056-010-9244-6

Hou YM, Quan YS, Cao J, Guan LH (2012) Study on superior family selection of Larix kaempferi. Journal of Central South University of Forestry and Technology 3(9): 6-10

Huang SW, Zhong WH, Chen BQ (2006) Estimation on genetic gains of combined selection for growth traits of half-sib progrny of Pinus taeda. Scientia Silvae Sinicae 42(4): 33-37

Isik K, Kleinschmit J, Steiner W (2010) Age-age correlations and early selection for height in a clonal genetic test of Norway spruce. Forest Science 56(2): 212-221

Israel C, Weller J (2000) Effect of misidentification on genetic gain and estimation of breeding value in dairy cattle populations. Journal of Dairy Science 83(1):181-188. https://doi.org/10.3168/jds.s0022-0302(00)74869-7

Jansson G, Li B, Hannrup B (2003) Time trends in genetic parameters for height and optimum age for parental selection in Scots pine. For Sci 49: 696-705

Jonah P, Aliyu B, Jibung G, et al. (2011) Phenotypic and genotypic correlation in bambara groundnut (Vigna subterranea (L.) Verdc) in Mubi, Adamawa State, Nigeria. World Journal of Agricultural Sciences, 7 (3) : 298-303

Kang $\mathrm{H}$ (1985) Juvenile selection in tree breeding: some mathematical models. Silvae Genet 34:75-84

Kaushik N, Deswal RPS, Malik S, Kumar K (2015) Genetic variation and heritability estimation in Jatropha curcas L. progenies for seed yield and vegetative traits. Journal of Applied and Natural Science 7(2):567-573 https://doi.org/10.31018/jans.v7i2.646

Kroon J, Ericsson T, Jansson G, Andersson B (2011) Patterns of genetic parameters for height in field genetic tests of Picea abies and Pinus sylvestris in Sweden. Tree Genet Genomes 7(6): 1099-1111 https://doi.org/10.1007/s11295-011-0398-y

Kumar D, Singh NB (2001) Age-age correlation for early selection of clones of Populus in India. Silvae Genet 50:103-108

Kumar S, Lee J (2002) Age-age correlation and early selection for end of rotation wood density in radiata pine. Forest Genetics 9(4): 323-330

Kung FH (1979) Improved estimators for provenance breeding values. Silvae Genetiea 28(2/3): 114-116

Kurinobu S (2005) Forest tree breeding for Japanese larch. Euras J Forest Res 8 : 127-134

Lai M, Sun X, Chen D, Xie Y, Zhang S (2014) Age-related trends in genetic parameters for Larix kaempferi and their implications for early selection. BMC Genet 15 Suppl 1:S10. https://doi.org/10.1186/1471-2156-15-s1-s10

Lee SJ, Woolliams J, Samuel CJ, Malcom DC (2002) A study of population variation and inheritance in sitka spruce. Part III. Age trends in genetic parameters and optimum selection ages for wood density, and genetic correlations with vigour traits. Silvae Genet 51:143-151

Leksono B, Kurinobu S, Ide Y (2006) Optimum age for selection base on a time trend of genetic parameters related to diameter growth in seedling seed orchards of Eucalyptus pellita in Indonesia. Journal of Forest Research 11: 359363. https://doi.org/10.1007/s10310-006-0223-X

Liang DY, Zhang XX, Wang C, Wang XW, Li KL, Liu GF, Zhao XY, Qu GZ (2018 a) Evaluation of Betula platyphylla families based on growth and wood properties traits. For. Sci. 64(6): 663-670. https://doi.org/10.1093/forsci/fxy027

Liang DY, Ding CJ, Zhao GH, Leng WW, Zhang M, Zhao XY, Qu GZ (2018 b) Variation and selection analysis of Pinus koraiensis clones in northeast China. J. For. Res. 29(3): 611-622. https://doi.org/10.1007/s11676-017-0471-y

Liu HW, Wang GY (2016) Fine families selectiong in half-sib progeny test of Larix gmelinii. Forestry Science and Technology 41(5):12-14

Liu MR, Yin SP, Si DJ, Shao LT, Li Y, Zheng M, Wang FW, Li SC, Liu GF, Zhao XY (2015) Variation and genetic stability analyses of transgenic TaLEA poplar clones from four different sites in China. Euphytica 2: 331-342 https://doi.org/10.1007/s10681-015-1471-7

Louzada J, Fonseca F (2002) The heritability of wood density components in Pinus pinaster Ait, and the implications for tree breeding, Ann. For. Sci. 59:867 873.https://doi.org/10.1051/forest:2002085

Ma S (2006) Studies on genetic variation and early selection of Japanese larch clones. M.S. Thesis of Henan Agricultural University 
Marques OG, Andrade HB, Ramalho MAP (1996) Assessment of the early selection efficiency in Eucalyptus cloeziana F. Muell. in the northwest of Minas Gerais state (Brazil). Silvae Genet 45(5-6):359-361

Montes CS, Hernandez RE, Beaulieu J, Weber JC (2008) Genetic variation in wood color and its correlations with tree growth and wood density of Calycophyllum spruceanum at an early age in the Peruvian Amazon. New Forest 35: 57-73. https://doi.org/10.1007/s11056-007-9060-9

Moriguchi Y, Kita K, Uchiyama K, Kuromaru M, Tsumura Y (2008) Enhanced hybridization rates in a Larix gmelinii var. japonica $\times$ L. kaempferi interspecific seed orchard with a single maternal clone revealed by cytoplasmic DNA markers. Tree Genetics and Genomes 4: 637-645 https://doi.org/10.1007/s11295-008-0139-z

Nakada R, Fujisawa Y, Taniguchi T (2005) Variations of wood properties between plus-tree clones in Larix kaempferi (Lamb.) Carrière. Bull For Tree Breed Cent 21: $85-105$

Pan XQ (2014) Genetic variation and selection of resin traits in Pinus elliottii. Mas ter Thesis of Jiangxi Agricultural University

Cáceres C B, Hernández R E, Fortin Y, et al. (2017) Wood density and extractive content variation among Japanese larch (Larix kaempferi [Lamb.] Carr.) progenies / provenances trials in eastern Canada. Wood \& Fiber Science Journal of the Society of Wood Science \& Technology 49(4): 363-372.

Silva F, Pereira MG, Ramos HC, Damasceno J, Pereira T, Gabriel A, Viana AP, Ferreguetti GA (2008) Selection and estimation of the genetic gain in segregating generations of papaya (Carica papaya L.). Crop Breeding \& Applied Biotechnology 8:1-8. https://doi.org/10.12702/1984-7033.v08n01a01

Sumida A, Miyaura T, Torii H (2013) Relationships of tree height and diameter at breast height revisited: analyses of stem growth using 20-year data of an even-aged Chamaecyparis obtusa stand. Tree Physiol 33: 106-118 https://doi.org/10.1093/treephys/tps127

Sun XM (2003) Selection of superior Larix kaempferi families for pulpwood purpose and family based growth simulation. Ph.D. Thesis of Chinese Academy of Forestry

Sun XM, Zhang SG, Hou YM, Li SY (2004) Age trends of genetic parameters for growth traits in short rotation Larix kaempferi families. Scientia Silvae Sinicae 40 (6): 68-74

Svensson J, McKeand S, Allen H, Campbell R (1999) Genetic variation in height and volume of loblolly pine open-pollinated families during canopy closure. Silvae Genet 48:204-8

Du CQ, Xu YZ, Sun XM, Liu YH, Xie PS (2015) Variation of growth traits and early selection of Larix kaempferi clones in sub-alpine area of western Hubei Province. Journal of Huazhong Agricultural University 34 (3): 19-23

Teruyoshi N, Kazutoshi N, Hiroshi Y, Yoshihiko T (2014) Provenance tests for survival and growth of 50-year-old Japanese larch (Larix kaempferi) trees related to climatic conditions in central Japan. Tree Genetics \& Genomes 10: 8799. https://doi.org/10.1007/s11295-013-0666-0

Toda R, Mikami S (1976) The provenance trials of Japanese larch established in Japan and the tentative achievements. Silvae Genet 25: 209-216

Wang YC, Dong XG, Wang XS, Ma H (2000) Study on seed production and fruiting law of seed orchard in Larix kaempferi (Lamb.) carr. Scientia Silvae Sinicae 36(2): 53-59

Watanabe M, Watanabe Y, Kitaoka S, et al. (2011) Growth and photosynthetic traits of hybrid larch F1 (Larix gmelinii var. japonica $\times$ L. kaempferi) under elevated $\mathrm{CO} 2$ concentration with low nutrient availability. Tree Physiology 31(9): 965. https://doi.org/10.1093/treephys/tpr059

Wright JW (1976) Introduction to forest genetics. Academic Press 463

Xia H, Zhao GH, Zhang LS, Sun XY, Yin SP, Liang DY, Li Y, Zheng M, Zhao XY (2016) Genetic and variation analyses of growth traits of half-sib Larix olgensis families in northeastern China. Euphytica. https://doi.org/10.1007/s10681-016-1765-4

Xiang B, Li B, Isik F (2003) Time trend of genetic parameters in growth traits of Pinus taeda L. Silvae Genetica 52(3-4): 114-120

Yin SP, Zhao GH, Xia H, Sun XY, Pan YY, Wang FW, Li SC, Zhao XY (2016) Study on progeny test of half-sib families in Larix olgensis. Journal of Southwest Forestry University 36(1):63-68

Zas Arregui R, Merlo Sánchez E, Fernández López J (2004) Genetic parameter estimates for Maritime pine in the Atlantic coast of North-west Spain. Forest Genet 11(1): 45-53
Zeng LH, Zhang Q, He BX, Lian HM, Cai YL, Wang YS, Luo M (2013) Age trends in genetic parameters for growth and resin-yielding capacity in Masson Pine. Silvae Genetica 62:7-18. https://doi.org/10.1515/sg-2013-0002

Zhang ZG, Ma JW, Jin XC, Wang HC, Ding PJ, Hu MH, Pan CL, Lei SG (2013) Analysis and selection of progeny test forest of the open pollinated family of Japanese larch. Journal of Northwest Forestry University 28(4): 74-79

Zhang KZ (2013) Selection and open-pollinated progeny test for plus trees of $\mathrm{Pi}$ nus massoniana. Journal of Fujian Forestry Science and Technology (4): 4144

Zhao XY, Bian XY, Liu MR, Li ZX, Li Y, Zheng M, Teng WH, Jiang J, Liu GF (2014) Analysis of genetic effects on complete diallel cross test of Betula platyphylla. Euphytica 200:221-229. https://doi.org/10.1007/s10681-014-1147-8

Zhao XY, Hou W, Zheng HQ, Zhang ZY (2013a) Analyses of genotypic variation in white poplar clones at four sites in china. Silvae Genetica 62, 4-5: 187-195 https://doi.org/10.1515/sg-2013-0023

Zhao XY, Li Y, Zhao L, Wu RL, Zhang ZY (2013b) Analysis and evaluation of growth and adaptive performance of white poplar hybrid clones in different sites. Journal of Beijing Forestry University 35: 7-14

Zhao XY, Xia H, Wang XW, Wang C, Liang DY, Li KL, Liu GF (2015) Variance and stability analyses of growth characters in half-sib Betula platyphylla families at three different sites in China. Euphtyica 208 (1): 173-186 https://doi.org/10.1007/s10681-015-1617-7

Zheng R, Shi J, Xiao H, Huang JH, Su SD, Xu LP, OU YL, Zhang ZC, Ye DQ, Fang YH (2014) Genetic variation and early selection of growth traits in 8-year-old open-pollinated progenies of the (3rd) germplasm of Chinese fir. Journal of Nanjing Forestry University 38(6): 38-42

Zhou H, Fries A, Harry X (2014) High negative genetic correlations between growth traits and wood properties suggest incorporating multiple traits selection including economic weights for the future Scots pine breeding programs. Annals of Forest Science 71: 463-472 https://doi.org/10.1007/s13595-014-0359-3 